\title{
THE ADAPTATION OF ISLAMIC PRINCIPLES IN SARAWAK TRADITIONAL MALAY HOUSE
}

| Received July 28 th 2021 | Accepted November 18 ${ }^{\text {th }}, 2021$ | Available online December 15 2021 DOI http://dx. doi. org/10.18860/jia.v6i4.13031

\section{Adibah Yusuf}

Planning \& Development Studies

Faculty of Social Sciences and Humanities

Universiti Malaysia Sarawak (UNIMAS)

Sarawak, Malaysia.

yadibah@unimas.my

\section{Khairul Aidil Azlin Abd Rahman}

Department of Industrial Design,

Faculty of Design and Architecture,

Universiti Putra Malaysia,

Selangor, Malaysia

drkhairulazlin@gmail.com

\section{Azmal Sabil,}

Department of Architecture

Faculty of Civil Engineering and Built Environment, University Tun Hussein Onn Malaysia,

Johor, Malaysia

azmal@uthm.edu.my

\section{Nangkula Utaberta}

Department of Architecture

Faculty of Civil Engineering and Built Environment,

University Tun Hussein Onn Malaysia,

Johor, Malaysia

nangkula_arch@yahoo.com

\section{Nadzirah Yusuf}

Faculty of Psychology and Education,

Universiti Malaysia Sabah, Kota Kinabalu, Sabah Malaysia

\begin{abstract}
Historically, in the event of Islam's arrival in the Malay Archipelago, the ways of Islam were adapted to the lifestyle of the Malay community. It's part of modernizing traditional Malay thoughts (akliah) which is influenced by Islamic values and teachings. One of the manifestations of Islamic influence in the traditional Malay lifestyle can be identified from the design and characteristics of Traditional Malay houses, developed with underlying principles of Islam. This paper discusses the application of Islamic principles in Sarawak traditional Malay houses. The research was conducted on three traditional Malay houses chosen from Sarawak and located in Kuching, Sarawak. The methods of observation and case study were employed, focusing on the interior space of the house and certain other design components. In addition, interviews were performed with the owners of the three houses that comprised the samples and focus group discussions with 12 Malay people over 65. The findings indicate that three concepts may be related to Islam's characteristics in Sarawak: the concept of occupant socia connections, residential space, and construction and design
\end{abstract}

\section{KEYWORDS:}

Sarawak Traditional Malay House, Islamic Principles, Design

\section{INTRODUCTION}

The dwelling house is a fundamental institution that is important for human life and the development of a prosperous family. Every human being needs a habitable space that is free from external and environmental disruptions. (Surah al-Nahl, verses: 8081) [1]. Thus, the home is an integral aspect of the environment and directly impacts human development. Housing is the foundation for the construction and well-being of human life. It is because the house is more than a physical space; it serves as the hub of social interaction and the foundation for the development of a flourishing community. Islam has established precise criteria for the provision of highquality residential dwellings. Even, the house becomes a component of the overall quality of life satisfaction.

In line with the principles of Islam, the traditional Malay house was designed by our ancestors to meet their socioeconomic, cultural, and environmental needs. As a result, the built environment in the Malay traditional architecture era comfortably reacts to the contextual environment and appropriately serves the social needs of occupants and surrounding community [2], [3]. The traditional Malay house has its unique charm, as the construction and basic elements such as the house, tree, roof, sill, windows, and staircases are all constructed with distinct meanings. The house's architecture is frequently associated with the Malays' creative inclination and intimate interaction with the environment [4][5].

The house is a treasure, a sanctuary, and a place of worship in the world settled for inventory purposes hereafter for the Malay community, which is identical to Islam. The house is typically constructed with a concentration on comfort, safety, and art that reflect the uniqueness of the Malay community founded in Islamic culture. Furthermore, the Malay house structure incorporates components of Islamic law such as the separation of men's and women's bedroom, the main area with a back and forth [3] [4] 
[6]-[11]. This research focuses on the interior space of the house and some design elements of the Sarawak traditional Malay house, which are later associated with Islamic characteristics. It is another discipline of knowledge reflected in the architecture of the Sarawak Malay population, which has received less attention in recent years. As an outcome, this research analyzes the entire architecture of a traditional Malay house in Sarawak and associates it with the Malay world's impact and Islamic values. In other words, this research will look at traditional Malay houses that have been disregarded, as well as their relations to Islamic beliefs.

\section{METHODS}

The whole methodology was qualitative, incorporating case studies, fieldwork, and observation to obtain a comprehensive picture of the design space in Malay dwellings as a sample. Simultaneously, a measured drawing of the house's floor plan would be created to illustrate the house's primary areas. Additionally, this study included in-depth interviews with homeowners and focus group discussions with 12 villagers who were familiar and acquainted with Sarawak traditional Malay houses and their relations to Islamic traditions and values. The selection criteria for the study sample are listed in Table 1.

Table 1: Selection criteria for the study sample

\begin{tabular}{|c|c|c|}
\hline No. & Characteristics & Study Sample \\
\hline 1. & The house's age & Over the age of 80 \\
\hline 2. & $\begin{array}{l}\text { Elements of } \\
\text { Tradition }\end{array}$ & $\begin{array}{l}\text { The house preserves many } \\
\text { traditional features and char- } \\
\text { acteristics, including the roof, } \\
\text { windows, staircase, walls, and } \\
\text { sculptures. }\end{array}$ \\
\hline 3. & Material & $\begin{array}{l}\text { The majority of houses, partic- } \\
\text { ularly the front / primary resi- } \\
\text { dence, maintain their timber } \\
\text { walls. }\end{array}$ \\
\hline 4. & Ownership & Homeowners must be Malay \\
\hline
\end{tabular}

Table 2: The three houses that were sampled for this research.

\begin{tabular}{|c|c|c|c|}
\hline Sample & Addresses & $\begin{array}{c}\text { Estimated } \\
\text { Year of } \\
\text { Construction }\end{array}$ & $\begin{array}{c}\text { House's } \\
\text { age }\end{array}$ \\
\hline $\begin{array}{c}\text { Sample } \\
\text { A1 }\end{array}$ & $\begin{array}{l}\text { No. 328, Jalan } \\
\text { Datuk Ajibah } \\
\text { Abol, Kuching }\end{array}$ & In 1991 & $\begin{array}{c}110 \text { years } \\
\text { old }\end{array}$ \\
\hline $\begin{array}{c}\text { Sample } \\
\mathrm{A} 2\end{array}$ & $\begin{array}{c}\text { No. 71, Jalan } \\
\text { Muhibbah, } \\
\text { Kuching }\end{array}$ & In 1916 & $\begin{array}{c}105 \text { years } \\
\text { old }\end{array}$ \\
\hline $\begin{array}{c}\text { Sample } \\
\text { A3 }\end{array}$ & $\begin{array}{l}\text { No. 101, Kam- } \\
\text { pung Sungei } \\
\text { Bedil Besar, }\end{array}$ & In 1935 & $\begin{array}{c}86 \text { years } \\
\text { old }\end{array}$ \\
\hline
\end{tabular}

\section{FINDING AND DISCUSSION}

The findings indicated that three concepts might be related to Islam's characteristics in Sarawak: the traditional Malay house concept of occupant social relations, residential space, and construction and design.

\section{SOCIAL RELATIONS CONCEPT}

The outcomes of focus group discussions with 12 respondents indicated that a person's house becomes an institution early in life, which has been going on for a long time and has been passed down generation to generation among the Malay population in Sarawak. Islam recognizes that each spiritual fulfillment results in the individual's well-being. The following table (table 3) summarizes the ideas/ characteristics of Islam applied to the traditional Malay population of Sarawak, accompanied by scriptures from the Quran / Hadith.

Table 3: Islam's Fundamental Principles in house design and its relation to the Quran and hadith

\begin{tabular}{|c|c|c|}
\hline No. & $\begin{array}{l}\text { Islam's Fundamental } \\
\text { Principles/Characteristics }\end{array}$ & $\begin{array}{c}\text { Related } \\
\text { Quranic } \\
\text { verses/Hadith }\end{array}$ \\
\hline 1 & In Islam, the house serves as & Surah An-Nahl: \\
\hline 2 & $\begin{array}{l}\text { The leader of the family is } \\
\text { responsible for providing a } \\
\text { home/residence for the } \\
\text { family. }\end{array}$ & $\begin{array}{l}\text { Verse } 7 \text { of } \\
\text { Surah At-Talaq }\end{array}$ \\
\hline 3 & $\begin{array}{l}\text { The blessed filling of the } \\
\text { Qur'an, prayer, and } \\
\text { recollection blesses the } \\
\text { dwelling house. }\end{array}$ & $\begin{array}{l}\text { Surah al } \\
\text { Ankabut, Verse } \\
45(29)\end{array}$ \\
\hline 4 & $\begin{array}{l}\text { A dwelling house is a basic } \\
\text { institution that is very } \\
\text { important to human life and } \\
\text { the formation of a } \\
\text { prosperous family }\end{array}$ & $\begin{array}{l}\text { Surah al-Nahl } \\
\text { (16): } 80-81\end{array}$ \\
\hline 5 & Women's rights in Islam & $\begin{array}{l}\text { Verse } 195 \text { of } \\
\text { Surah Ali-Imran }\end{array}$ \\
\hline 6 & $\begin{array}{l}\text { Preserve the aura and } \\
\text { privacy of the house }\end{array}$ & $\begin{array}{l}\text { Verse } 27-28 \text { of } \\
\text { Surah An-Nur }\end{array}$ \\
\hline 7 & Welcoming guests & $\begin{array}{l}\text { Verse } 24-27 \text { of } \\
\text { Surah Al- } \\
\text { Dzariyat }\end{array}$ \\
\hline 8 & Islam's Feast & $\begin{array}{l}\text { Verse } 286 \text { of } \\
\text { Surah Al- } \\
\text { Baqarah }\end{array}$ \\
\hline 9 & Respect the neighbors & $\begin{array}{l}\text { Verse } 36 \text { of } \\
\text { Surah An-Nisa }\end{array}$ \\
\hline
\end{tabular}

Individuals should be provided personal time and space in Islam to do whatever they want, including worship and other daily routines. Indeed, every Muslim is responsible for constantly developing to achieve prosperity in this world and the hereafter.

On the other side, the house functions as a focal point for family activities in meeting physical and

211 | Journal of Islamic Architecture, 6(4) December 2021 
spiritual requirements [12]. The spiritual filling related to the dwelling is important and directly correlates with the Muslim family's well-being. The Islamic family institution is concerned with the physical development and space of the dwelling house and the filling of useful space. It brings about kindness in this world and the hereafter. A family's structure and well-being begin with a good, excellent, and convenient dwelling place. Islam promotes balance as a way of life. Therefore, a healthy balance of physical and spiritual demands is critical for establishing a blessed habitation [12].

\section{ISLAM'S CONCEPT OF LIVING SPACE}

As with traditional Malay dwellings, certain implied norms apply. The organization of spaces and their elements appear to be structured, and the occupants have a rationale for doing so. Table 4 shows a brief overview of designated rooms in the sampled houses. The three sampled houses shared the same spatial design characteristics, divided into three distinct areas: an entry hall or front space, a living room or central space, and a backspace.

\begin{tabular}{l} 
Table 4: Space design in the sampled houses \\
\hline Code \\
Sample \\
photo
\end{tabular}

\begin{tabular}{|c|c|}
\hline $\begin{array}{l}\text { Space } \\
\text { design }\end{array}$ & $\begin{array}{l}\text { Design of a space } \\
\text { 1. The front space } \\
\text { 2. The central area } \\
\text { 3. Back space } \\
\text { 4. The front 'Teko.' } \\
\text { The design of the spaces in this house has } \\
\text { never been altered. }\end{array}$ \\
\hline Code & House $A_{3}$ \\
\hline \multicolumn{2}{|l|}{$\begin{array}{l}\text { Sample } \\
\text { photo }\end{array}$} \\
\hline \multirow{7}{*}{$\begin{array}{l}\text { Space } \\
\text { design }\end{array}$} & Design of a space \\
\hline & 1. The front space \\
\hline & 2. The central area \\
\hline & 3. Back space \\
\hline & 4. The front 'Teko.' \\
\hline & $\begin{array}{l}\text { 5. Verandah/"serambi" at the side of the } \\
\text { house }\end{array}$ \\
\hline & $\begin{array}{l}\text { Renovations have taken place in this } \\
\text { house's interior. }\end{array}$ \\
\hline
\end{tabular}

\section{DISCUSSION}

HOUSE A1

This house, which is Located at No. 328, Jalan Datuk Ajibah Abol, Kuching, is the first sample house. This house dates back to 1911. It is the most extended traditional Malay house in Kuching's Malay villages. The space in this residence is depicted in figure 1.

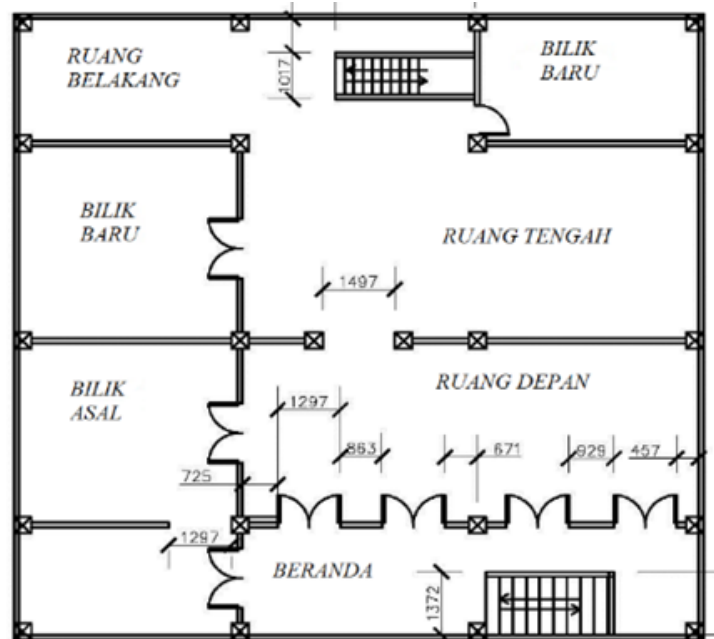

Figure 1: Layout of House $A 1$

Originally, this house had three main spaces: the front space, the center space, and the backspace, as well as a front veranda. According to the owner of this house, the original room is simply a room, while the rest of the space is an extension to the house's 
original space plan.

The sections of this house have been segregated according to their intended purposes and functions. For instance, the front space, often known as the main space, is designated to entertain male guests, while the center space is for female guests. Additionally, a separate kitchen was positioned on the spacious rare, and according to homeowners interviewed, it was in keeping with the Malays' cooking culture, which includes feasting activities. This distribution and structure demonstrate that the traditional Malay community in Sarawak follows religious values when it comes to the spatial design of the house.

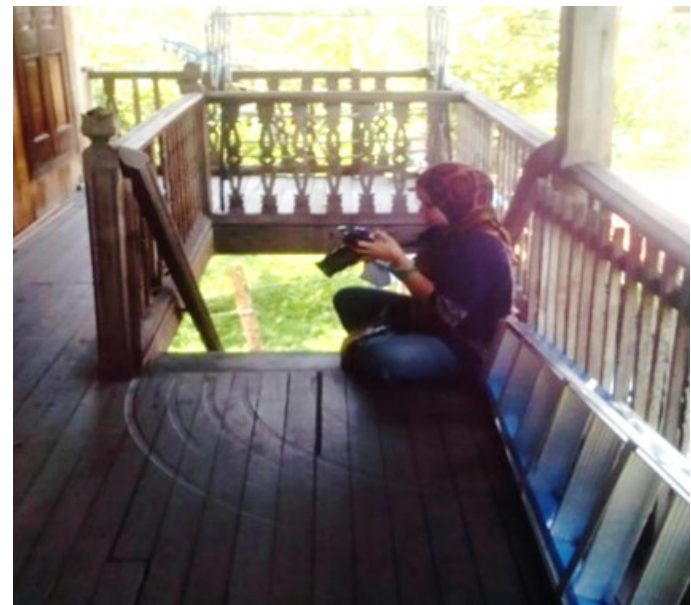

Figure 2: The verandah at the frontal part of House A1

After that, there is a veranda in front of the house that is typically utilized to greet the male guests and provide a space for men to converse (figure 2 ). This veranda functions as an unwind space in the evening and a congregational place for men when a feast or gathering is held in a residence/house. Outsiders, especially men who are not mahram, are usually prohibited from entering the house without the host's permission, especially if the residence has a daughter. Thus, it becomes a symbol of how the Malays concern about social conventions and discipline.

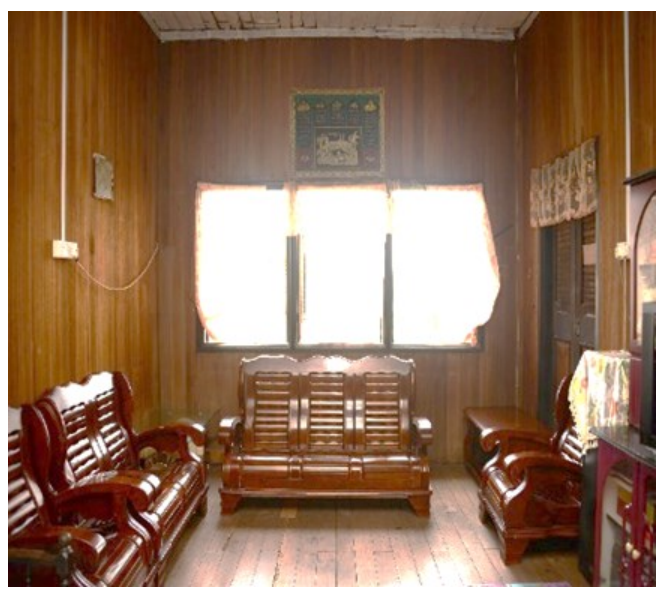

Figure 3: The main space of house A1(Living area)
In Sarawak, the Malay community living area serves as a congregational space for the family. But, in the event of a key ceremony during feasts, it serves as a space for the "bergendang" and "bertandak." In controlling the segregation between males and females, the non-mahram male guests are restricted in the verandah. In contrast, female guests are usually allowed to be in the living room and mostly in the kitchen area.

In other words, a residential home is a private space for individuals and families. Outsiders are not permitted to enter and exit a residence unless they have permission to do so. The legal basis for entering a dwelling is based on Allah SWT's words: (Surah an-Nur, verses: $27-28)[1]$

\section{HOUSE A2}

Located at No. 71, Jalan Muhibbah, Kuching, this house contains three main spaces: the front (reception space), the center space, and the backspace.

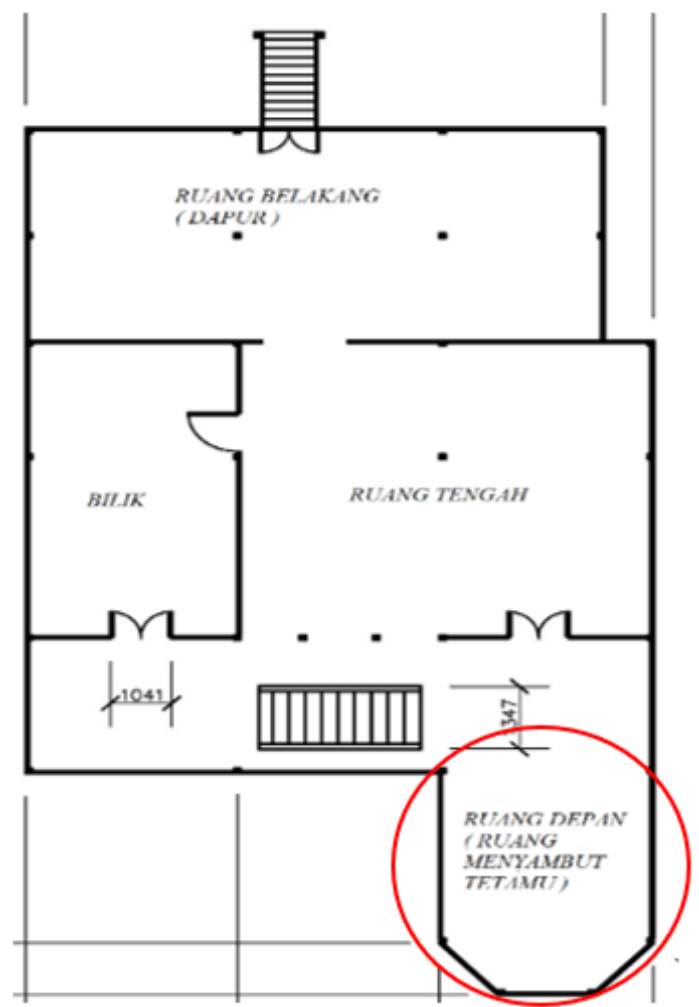

Figure 4: Layout of House A2, with the remark of 'teko' area in the red circle

In contrast to the first house sample, house $A 2$ does not have a veranda but rather a place known as a "teko" is in front of the house. This "teko" room is where guests are placed when they visit the house (refer to figure 4). The separation of the "teko" space from the central space shows that the construction of this house also highlights the significance of safeguarding the tenants' privacy. Guests are only permitted to enter the "teko" space and are not allowed to enter the middle or rear spaces without the 
host's consent. As a result, it's unsurprising that a door separates the path to the "teko" space from the house's central space.

The middle space has a bedroom and space for several primary activities such as recitation and prayer, while the backspace consists of a kitchen. According to the owner of this house, the dining room and kitchen are typically positioned toward the back of the house to allow women to do their daily duties without distraction, which is also consistent with Islam's emphasis on women's dignity.

In other words, the space design for house A2 incorporates Islamic characteristics, such as segregating male and female guests. Males often congregate in the "teko" location rather than the central space (living room) and kitchen, which women utilize to converse and cook meals. As a result, this "teko" space is intended for male guests, whereas the kitchen or backspace is intended for female guests. This follows the Prophet Muhammad SAW's hadith, which calls for the restriction of male-female relationships [13].

\section{HOUSE A3}

The third house is located at 101, Kampung Sungei Bedil Besar, Kuching. Originally, this house featured three main spaces: the front space (reception room), the center space, and the backspace, in addition to a side veranda (refer to figure 5). Typically, the verandas are not fully enclosed by a high wall, but by a half-foot wall or fence. This space frequently serves as a link between the outside and interior of the house, allowing for work, relaxation, and the reception of non-stranger guests. This location is also frequently utilized by male inhabitants to do daily activities such as weaving fishing nets or having afternoon tea.

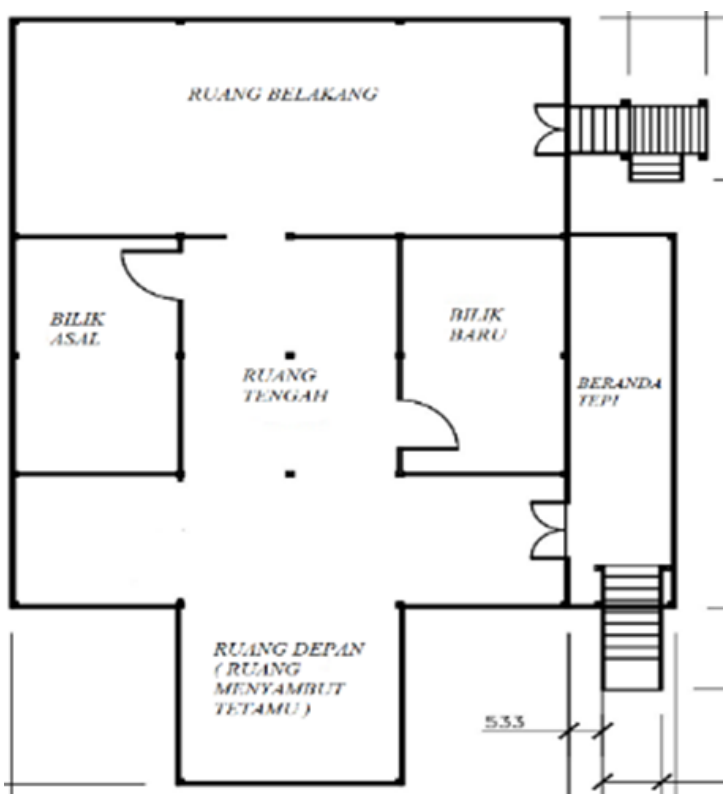

Figure 5: Layout of House $A_{3}$
Originally, the house contained only one room. When necessary, the spaces are divided by a curtain to segregate privacy in certain house areas. Tapestries between a male's and a female's room, for instance, are installed. Curtains are also placed in the beds of parents and children who have grown up or achieved puberty. Taverns between the living rooms are installed to avoid direct views into the interior area of the house. In this way, the privacy of the family members, particularly women, is protected.

The topic of privacy in residential houses is vital for every individual, family, or community to understand, and it is part of the human agenda in everyday life [14]. As mentioned in various early studies by Shariah scholars, Islam views privacy as one of the rights in human life. Muhammad [15] and al-Jundiyy [16] use the terms al-Hayat al-Hadassah and alKhususiyyah to refer to privacy, defined as a solitary position without disturbance. The wisdom of this law is to avoid paying attention to the badness or mistakes of the dwelling's occupants. Additionally, requesting permission allows the host time and chance to prepare for the presence of outsiders. Respect for the rights of others is also required, as the residence is private property that can only be accessed via authorized routes. Apart from that, each view expressed by the house's residents shows the presence of spatial disparities within the house. Each has a private place for secret and confidential activity.

\section{CONCEPTS FOR CONSTRUCTION AND DESIGN}

\section{- Construction of a traditional Malay house in Sarawak}

The art of traditional construction methods focuses on how a traditional house is constructed utilizing locally available resources. Traditional Malay House Sarawak also utilized traditional construction methods such as pegs and mortise to reinforce and fortify the structure. Apart from the typical Malay home construction, Sarawak prioritizes facing Mecca while building a house. Additionally, it is constructed towards the rising or setting of the sun to align with the direction of Qibla and to regulate the temperature in the house [17]

\section{- Stairs Design}

Stairs of Sarawak traditional Malay houses are frequently constructed with an odd number as perfection, implying that it belongs exclusively to Allah S.W.T. The odd number depicts man as a feeble and imperfect servant of God. Typically, the Malay traditional society will take steps $3,5,7$, and 9. The number seven is frequently related to the meanings of seven petals in the sky, seven petals on the ground, and seven days. Thus, it is apparent that the traditional Malay civilization frequently incorporates the Quranic verses into the building of their houses. 

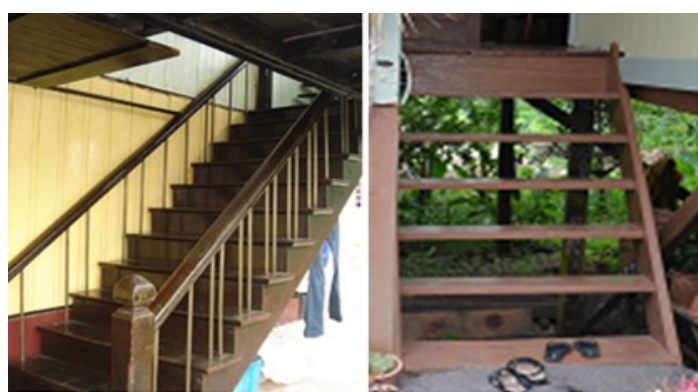

Figure 6: The odd numbers of steps in House $A 2 \& A 3$

\section{- Tunjok Langit}

"Tunjok langit" refers to the timber that has been strewn across the roof, as depicted in figure 7 and figure 8. It is called "tunjok langit" because the timber is put in an upward direction. "Tunjok langit" is typically posted a stem or two stems in a traditional Malay dwelling (pair). However, in Sarawak, the majority of "tunjok langit" is mounted on one. The "tunjok langit" placed on a stick symbolises the monotheistic faith in front or in other areas. Apart from that, the "tunjok langit" put on a pole indicates the residents of the house's trust in one God.

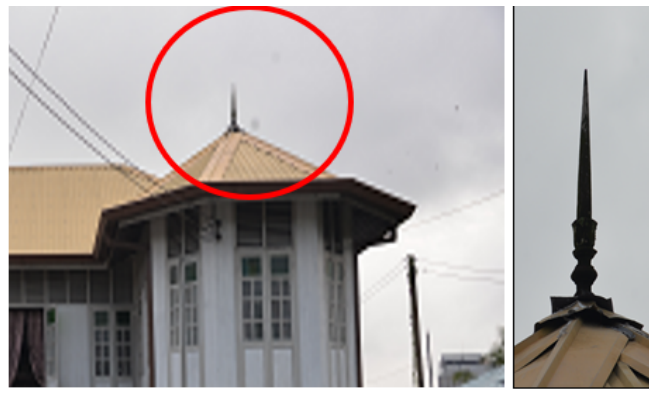

Figure 7: Tunjok langit was found in House A2 (Red Circle)

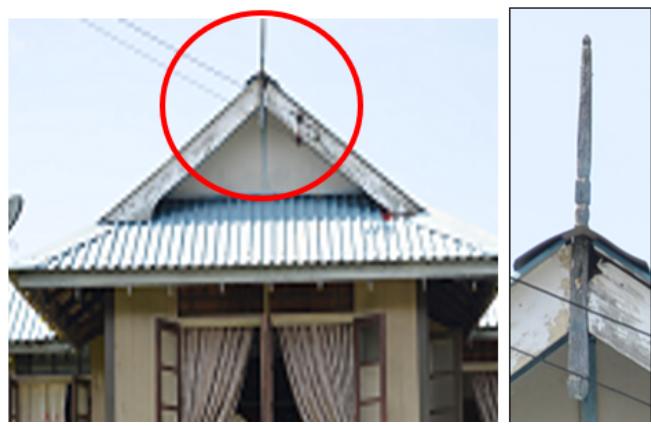

Figure 8: Tunjok langit was found in House $A_{3}$ (Red Circle)

\section{CONCLUSION}

In conclusion, Islam has a considerable influence on the construction of residential dwellings in Sarawak and the characteristics of Islam dictating the structure and area of the dwelling. This is because, for them, home is a place to nurture a family, to shape a true Muslim personality in children and family members, a place to calm the heart, soul, and relax, a place separated from the outside world, and a place to practice Islamic etiquette. But, aside from that, the house is where people can grow closer to Allah SWT and achieve the highest level of faith.

However, the use of residential space has changed significantly in recent years due to the use and advancement of technology. It should not be an issue, however, as long as it contributes to achieving a level of comfort while still emphasizing Islamic values and characteristics in the structure and design of its construction, so that it is safe and comfortable for its occupants and thus contributes to further strengthening the relationship with Allah SWT.

\section{ACKNOWLEDGEMENT}

This research is supported by the Fundamental Research Grant Scheme for Research Acculturation of Early Career Researchers, Ministry of Higher Education Malaysia (RACER/1/2019/SSI11/UNIMAS//2), Project ID 16436

\section{REFERENCES}

[1] Al-Quran Dan Terjemahannya, Mujamma'. alMalik al-Fahd, Madinah alMunawwarah: Saudi Arabiyya, 1990

[2] G. Mursib \& R. Mohamad, "The Basic Malay House", in C. V. Fee, The Encyclopedia of Malaysia Architecture, pp. 20-22, Kuala Lumpur: Archipelago Press, 1998

[3] M. Surat, "Peranan Budaya Bangsa Dalam Pembangunan Senibina Malaysia, Garapan Dari Teras Senibina Warisan Melayu", Seminar Falsafah Sains Teknologi 2, pp. 1-27, Kajang: Insititut Penyelidikan Anwar Ibrahim, 2016.

[4] W. Hashim, \& A. H. Nasir, The Traditional Malay House, Kuala Lumpur: Institut Terjemahan Negara Malaysia, 2011.

[5] L. J. Yuan, The Malay House: Rediscovering Malaysia's Indigenous Shelter System, Kuala Lumpur: Institut Masyarakat/Central Book Ltd, 1991.

[6] A. Sabil, The Ideas and approaches of Modern Malay Architecture Among Architects in Malaysia, PhD Thesis, University Putra Malaysia, Serdang, 2020.

[7] N. H. M. Razali and A. Talib, "The Concept of Privacy and the Malay Dwelling Interior Space Planning", Procedia - Social and Behavioral Sciences, vol. 101, no. 8, pp. 404-414, 2013, doi: 
https://doi.org/10.1016/j.sbspro.2013.07.214

[8] W. N. W. Ismail, F. Arabi, E. M. Husini, F. N. S. Zolkifly, Z. M. Darus, N. H. A. Jaafar, A. A. Manaf, "The Establishment of Islamic Dwelling Principles for the Malaysian Communities", Advanced Science Letters, vol. 23, No. 7, pp. 6289-6293, 2017, doi: https://doi.org/10.1166/ asl.2017.9254.

[9] Z. Othman, R. Aird, L. Buys, "Privacy, modesty, hospitality, and the design of Muslim homes: A literature review", Frontiers of Architectural Research, vol 4, no. 1, pp. 12-23, 2015, doi: https://doi.org/10.1016/i.foar.2014.12.001

[10] A. N. A. Hwaish, "Concept Of The Islamic House; A Case Study Of The Early Muslims House", Proceedings of 4th IASTEM International Conference, 2015

[11] H. Babangida, H. S. Katsina, "Integrating Islamic Design Principles for Achieving Family Privacy in Residential Architecture", Journal of Islamic
Architecture, vol. 5, no. 1, pp. 9-19, 2018, doi: DOI: https://doi.org/10.18860/jia.v5i1.4407

[12] A. Al-Sacad, Dawabit Bina' al-Masakin fi al-Fiqh al -Islamiyy, 2004, available at www.arablawinfo.com. (accessed 20 July 2010).

[13] A. A. Ghani, "Batas-batas Pergaulan Antara Lelaki dan Perempuan Dalam Masyarakat Islam Kini: Satu Huraian Hukum Islam Semasa", Jurnal Syariah, pp. 23-30, 1999

[14] M. T. M. Rasdi, Housing Crisis: Back to A Humanistic Agenda. Johor: Penerbit Universiti Teknologi Malaysia, 2007

[15] M. R. al-Dughmiyy. Himayat al-hayat al-khassah fi al-shari'ah al- Islamiyyah. Kaherah: Dar alSalam, 1985.

[16] H. al-Jundiyy, Damanat hurmat al-hayat alkhassah fi al-Islam, Kaherah: Dar al- Nandah alcArabiyyah, 1993. 